\title{
Analisis Antrian Pelayanan Tiket Bioskop di Makassar
}

\author{
Rasmini $^{1, a)}$,Hisyam Ihsan $^{1}$, Maya Sari Wahyuni ${ }^{1}$ \\ ${ }^{1}$ Jurusan Matematika FMIPA Universitas Negeri Makassar, 90224 \\ a) rasminisinjai@gmail.com
}

\begin{abstract}
Abstrak. Pada umumnya antrian yang cukup panjang dapat menimbulkan ketidaknyamanan para pengunjung. Oleh karena itu efesiensi waktu pelayanan merupakan hal yang menarik untuk dikaji. Permasalahan yang dikaji adalah mengenai sistem antrian pelayanan pembelian tiket di Bioskop 21 Mall Panakkukkang. Penelitian ini bertujuan untuk mengetahui model antrian yang diterapkan di Bioskop 21 Mall Panakkukkang. Dalam proses analisis dilakukan perhitungan secara manual dan menggunakan software Microsoft Visual Basic sebagai pembandingnya. Berdasarkan hasil analisis data yang diperoleh, struktur antrian yang diterapkan pada pelayanan pembelian tiket di Bioskop 21 Mall Panakkukkang adalah Singel Channel Single Phase. Model yang diterapkan adalah (M/M/1):(FCFS/00/0). Diambil data selama 3 hari dan diperoleh hasil perhitungan rata-rata antara lain: $\lambda_{\text {rata-rata }}=0,59 \frac{\text { pengunjung }}{\text { menit }}, \mu_{\text {rata-rata }}=$ $1,94 \frac{\text { pengunjung }}{\text { menit }}, \quad \rho_{\text {rata-rata }}=0,31 \%, \quad \rho_{\text {orata-rata }}=0,69 \%, \quad L q_{\text {rata-rata }}=0,13 \frac{\text { pengunjung }}{\text { menit }}$, $L s_{\text {Rata-rata }}=0,44 \frac{\text { pengunjung }}{\text { menit }}, W q_{\text {rata-rata }}=0,22$ menit, $W s_{\text {rata-rata }}=0,74$ menit. Antrian pada penelitian ini dikatakan sudah optimal dikarenakan lama pelayanan setiap pengunjung pembelian tiket Bioskop telah memenuhi standar pelayanan. Sedangkan untuk antrian pengunjung yang akan mendapatkan pelayanan telah optimal. Hal ini dikarenakan lama waktu menunggu dan lama waktu pelayanan pada loket terbilang singkat. Sehingga tidak perlu dilakukan penambahan ataupun pengurangan jumlah server pelayanan yang disediakan.
\end{abstract}

Kata Kunci: Teori Antrian, Singel Channel Single Phase, Distribusi Poisson, Distribusi Eksponensial, Simulasi.

\begin{abstract}
The average number of long lines can cause discomfort to visitors. Therefore the efficiency of the service time is an interesting thing to learn. The problem studied is about the queue system ticket purchase service at Cinema 21 Mall Panakkukkang. This study aims to determine the queue model applied in the Cinema 21 Mall Panakkukkang. In the process of analysis the calculation is done manualy and using Microsoft Visual Basic as a comparison. Based on the results of the analysis of the data obtained, the structure of the queue applied to the ticket pusrchase service at Cinema 21 Mall Panakkukang is Singel Channel Single Phase. The model applied is the (M/M/1):(FCFS/00/00). Data taken for 3 days and the obtained results of the average calculation, among others $\lambda_{\text {rata-rata }}=0,59$ visitor $/$ minute, $\boldsymbol{\mu}_{\text {rata-rata }}=1,94$ visitor $/$ minute $, \quad \rho_{\text {rata-rata }}=0,31 \%, \quad \rho_{\text {orata }- \text { rata }}=0,69 \%, \quad L q_{\text {rata-rata }}=$ 0,13 visitor $/$ minute, $\quad L s_{\text {Rata-rata }}=0,44$ visitor $/$ minute, $\quad W q_{\text {rata-rata }}=0,22$ minute, $W s_{\text {rata-rata }}=0,74$ minute. This queue on the study is said to be optimal due to the long service each visitor the purchase of a Cinema ticket has meet the service standards. While for the queue of visitors who will get the service has been optimal. This is because the long waiting time and long time service at the counter is fairly short. So no need to do addition or subtraction the number of service servers provided.

Keywords: Queuing Theory, Single Channel Single Phase, Distribution Poisson, Distribution Exponential, Simulation.
\end{abstract}




\section{PENDAHULUAN}

Antrian ialah item-item atau orang-orang dalam suatu baris yang menunggu dilayani. Antrian merupakan hal penting dalam manajemen operasi. Sistem antrian bisa diketemukan pada sektor industri maupun sektor jasa. Antrian bisa barisan orang atau barang yang menunggu untuk dilayani dan meninggalkan barisan setelah dilayani dan meniggalkan barisan setelah dilayani (Heizer \& Render, 2005).

Teori antrian atau sering disebut queuing theory merupakan sebuah bagian penting operasi dan juga alat yang sangat berharga bagi manajemen operasi. Aplikasi teori antrian sering terjadi dalam kehidupan sehari-hari. Adanya jumlah pelayan (server) yang terbatas dalam memenuhi permintaan pelayanan pelanggan (customer) mengakibatkan terjadinya antrian yang panjang. Pada dasarnya teori antrian berkenaan dengan seluruh aspek dari situasi dimana pelanggan harus antri untuk mendapatkan suatu layanan (Silaban \& Sulfin, 2015).

Beberapa peneliti telah mengkaji permasalahan mengenai analisis antrian (Jatmika \& Prasetyo, 2017; Setyawan, 2013; Serlina, 2018; Ratnasari, Rahadian, \& Liquidannu, 2018; Andika, Pardede, \& Vovriyenni, 2018; Arwindy, Bu'ulolo, \& Rosmaini, 2014; Suhartini, 2017). Serlina, (2018) meneliti tentang analisis antrian yang diselesaikan dengan mengevaluasi bentuk model antrian yang digunakan Bank dalam memberikan pelayanan. Suhartini (2017) meneliti tentang cara mendapatkan hasil ukuran-ukuran dasar dari kinerja sistem antrian yang akurat. Jatmika \& Prasetyo (2017) meneliti tentang analisis antrian untuk mengukur tingkat kepuasan pelayanan yang diberikan perguruan tinggi sehubungan dengan berapa cepat pemenuhan kebutuhan mahasiswa dibidang akademik.

Penelitian ini menganalisis model antrian dan mensimulasikan model tersebut dengan menggunakan software Visual Basic. Penelitian ini bertujuan untuk menganalisis model antrian pada sistem pelayanan bioskop, mensimulasikan model antrian pada bioskop serta mengevaluasi sistem antrian pada bioskop.

\section{KAJIAN PUSTAKA}

Retnaningsih \& Irhamah (2011) mengemukakan bahwa disiplin antrian adalah aturan dimana para pelanggan dilayani, atau disiplin pelayanan (service discipline) yang memuat urutan (order) para pelanggan menerima layanan. Disiplin antrian adalah konsep membahas mengenai kebijakan dimana para pelanggan dipilih dari antrian untuk dilayani, berdasarkan urutan kedatangan pelanggan. Ada empat bentuk disiplin pelayanan yang biasa digunakan dalam praktek yaitu :

1. First Come First Served (FCFS) atau First In First Out (FIFO)

2. Last Come First Served (LCFS) atau Last In First Out (LIFO)

3. Service In Random Order(SIRO)

4. Priority Service (PS)

Menurut Sinalungga (2008), desain sarana pelayanan dapat diklasifikasikan dalam channel dan phase yang akan membentuk sutu struktur antrian yang berbeda-beda. Channel menunjukkan jumlah jalur untuk memasuki system pelayanan. Phase berarti jumlah stasiunstasiu pelayanan, dimana para langganan harus melaluinya sebelum pelayanan dinyatakan lengkap. Ada empat model struktur antrian dasar yang umum terjadi dalam seluruh sistem antrian :

1. Single Channel-Single Phase.

2. Single Channel-Multi Phase

3. Multi Channel-Single Phase.

4. Multi Channel-Multi Phase. 
Ada beberapa penaksir parameter yang digunakan dalam analisis sistem antrian, diantaranya sebagai berikut :

\section{Parameter $\lambda$}

Parameter $\lambda$ menyatakan tingkat kedatangan pelanggan. Mencari nilai taksiran dilakukan observasi Likelihood dari data yang diamati melalui fungsi Poisson berdasarkan persamaan (1).

$$
\mathrm{L}(\text { Narrival } / \lambda)=\frac{(\lambda \mathrm{T})^{\mathrm{N}} \mathrm{e}^{\lambda \mathrm{T}}}{\mathrm{N} !}
$$

\section{Parameter $\mu$}

$\frac{1}{\mu}$ merupakan parameter waktu pelayanan rata-rata yang didapat dari data pengamatan. Menaksir parameter $\mu$ yaitu dengan mencari rata-rata langsung dari data waktu pelayanan dari pengamatan, berdasarkan persaman (2).

$$
\frac{1}{\mu}=\frac{\sum_{\mathrm{n}-1}^{\mathrm{N}} \mathrm{x}_{\mathrm{n}}}{\mathrm{N}} \text { menit/pelanggan }
$$

Karakteristik dan asumsi dari model antrian dirangkum dalam bentuk notasi. Menurut Kakiay (2004) bentuk kombinasi proses kedatangan dan pelayanan pada umumnya dikenal sebagai standar universal. Model-model antrian secara umum antara lain adalah sebagai berikut :

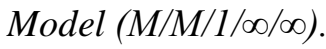

Berikut adalah persamaan-persamaan untuk model antrian pelayanan model ini:

1. Probabilitas fasilitas pelayanan sibuk dapat didefenisikan dalam persamaan (3).

$$
\rho=\frac{\lambda}{\mu}
$$

2. Probabilitas terdapat nol unit dalam sistem dapat didefenisikan dalam persamaan (4).

$$
\mathrm{P}_{0}=1-\frac{\lambda}{\mu}
$$

3. Jumlah rata-rata pelanggan yang menunggu dalam antrian dapat didefenisikan dalam persamaan (5).

$$
\mathrm{L}_{\mathrm{q}}=\frac{\rho\left(\frac{\lambda}{\mu}\right)}{(1-\rho)^{2}} \rho_{0}
$$

4. Jumlah rata-rata pelanggan yang menunggu dalam sistem dapat didefenisikan dalam persamaan (6).

$$
\mathrm{L}_{\mathrm{s}}=\mathrm{L}_{\mathrm{q}}+\frac{\lambda}{\mu}
$$

5. Waktu rata-rata menunggu dalam antrian dapat didefenisikan dalam persamaan (7).

$$
\mathrm{W}_{\mathrm{q}}=\frac{\mathrm{L}_{1}}{\lambda}
$$

6. Waktu rata-rata menunggu dalam sistem (antrian + pelayanan) dapat didefenisikan dalam persamaan (8).

$$
\mathrm{W}_{\mathrm{s}}=\mathrm{w}_{\mathrm{q}}+\frac{1}{\mu}
$$

\section{Model $(M / M / S / \infty / \infty)$.}

Pada model ini fasilitas pelayanan (server) bersifat ganda, rata-rata tingkat kedatangan lebih kecil dari pada penjumlahan seluruh ratarata tingkat pelayanan di semua jalur. Syarat yang lain sama dengan model server tunggal. 
Model $(M / M / 1 / N / \infty)$.

Model ini merupakan variasi dari model yang pertama, dimana panjang antrian atau kapasitas tunggu dibatasi maksimum $\mathrm{N}$ individu. Jumlah maksimum ini meliputi individu yang menunggu dan yang sedang dilayani.

Pada model ini terdapat hubungan saling ketergantungan antara panjang antrian dan tingkat kedatangan.

Model $(M / M / 1 / \infty / N)$.

Model ini hampir sama dengan model yang pertama hanya saja sumber populasi pada model ini dibatasi sebanyak $\mathrm{N}$.

Beberapa peneliti telah mengkaji permasalahan mengenai analisis antrian (Jatmika \& Prasetyo, 2017; Setyawan, 2013; Serlina, 2018; Ratnasari, dkk, 2018; Andika, dkk, 2018; Arwindy, dkk, 2014; Suhartini, 2017). Serlina, (2018) meneliti tentang analisis antrian yang diselesaikan dengan mengevaluasi bentuk model antrian yang digunakan Bank dalam memberikan pelayanan. Pada penelitian ini, mengusulkan model suatu sistem antrian baru yang sesuai dengan jenis pelayanan yang diberikan, sehingga mampu memberikan hasil pelayanan yang lebih baik dan memberikan waktu tunggu yang lebih kecil dan optimal dari model antrian sebelumnya. Suhartini (2017) meneliti tentang cara mendapatkan hasil ukuran-ukuran dasar dari kinerja sistem antrian yang akurat dengan bantuan software POM for Windows 3. Pada penelitian ini, menggunakan model $(\mathrm{M} / \mathrm{G} / \mathrm{C}): \mathrm{GD} / \infty / \infty)$ karena sistem antrian yang diterapkan termaksud dalam model multi channel berarti bahwa banyak jalur untuk memasuki sistem pelayanan atau banyak sistem pelayanan serta multi phase berarti bahwa banyak pelayanan atau banyak operasi yang dilaksanakan. Jatmika \& Prasetyo (2017) meneliti tentang analisis antrian untuk mengukur tingkat kepuasan pelayanan yang diberikan perguruan tinggi sehubungan dengan berapa cepat pemenuhan kebutuhan mahasiswa dibidang akademik. Hasil analisis menunjukkan bahwa model jenis antrian pelayanan akademik yang digunakan adalah jenis antrian model multi channel-singel phase dengan menerapkan disiplin antrian yaitu First In -First Out (FIFO).

\section{METODE PENELITIAN}

Penelitian ini merupakan penelitian terapan yang dilakukan dengan metode observasi. Data diperoleh secara langsung dengan memperhatikan waktu kedatangan dan waktu lama pelayanan setiap pengunjung pada sistem antrian yang ada pada Cinema 21 Mall Panakkukkang, Makassar, Sulawesi Selatan. Pengambilan data berlangsung selama 3 jam setiap hari Sabtu yaitu pada tanggal 09, 16, dan 23 Februari 2019. Penelitian ini bertujuan untuk menganalisis model antrian, mensimulasikan sistem antrian, dan mengevaluasi sistem antrian.

Dalam menganalisis model antrian, diperlukan data real kemudian data tersebut diolah dengan cara hitung manual. Selanjutnya, data yang sudah diolah disimulasikan menggunakan software visual basic. Setelah data disimulasikan maka langkah terakhir adalah mengevaluasi data sehingga dapat diperoleh kesimpulan suatu penelitian.

\section{HASIL DAN PEMBAHASAN}

Pada pelayanan pembelian tiket di Bioskop 21 Mall Panakkukkang terdapat tiga server pelayanan yang disediakan untuk melayani pengunjung yang akan melakukan pembelian tiket, tetapi hanya satu saja server yang sering digunakan dikarenakan server lainnya sibuk. Mekanisme kedatangan pengunjung untuk mendapatkan pelayanan pembelian tiket di bioskop 21 Mall Panakkukkang diawali ketika pengunjung datang untuk diperiksa barang bawaan seperti makanan sebab di dalam bioskop tidak diperbolehkan membawa makanan dari luar bioskop tersebut. Ketika pengunjung 
telah menyiapkan nama film yang akan di tonton, pengunjung langsung ke loket pembelian tiket. Pada saat itu pula, pengunjung telah masuk ke dalam sistem antrian pelayanan pembelian tiket. Para pengunjung dianggap telah keluar dari sistem bilamana pengunjung tersebut telah menyelesaikan proses pembelian tiket bioskop pada loket pembelian tiket bioskop. Ada beberapa tahapan yang mesti dilalui pengunjung untuk pembelian tiket sebelum terselesaikan yaitu:

1. Loket pembelian tiket

2. Pembayaran tiket

3. Pembelian tiket

Data hasil pengamatan yang telah dilakukan di Bioskop pada hari Sabtu, 09 Februari 2019 hingga Sabtu, 23 Februari 2019 dapat dilihat pada Tabel 1.

TABEL 1. Data kedatangan (K) dan waktu pelayanan (P) pengunjung

\begin{tabular}{ccccccc}
\hline \multirow{2}{*}{ Waktu } & \multicolumn{2}{c}{ Sabtu 9 Februari } & \multicolumn{2}{c}{ Sabtu 16 Februari } & \multicolumn{2}{c}{ Sabtu 23 Februari } \\
& \multicolumn{2}{c}{2019} & \multicolumn{2}{c}{2019} & 2019 \\
\cline { 2 - 7 } & $\mathrm{K}$ & $\mathrm{P}$ & $\mathrm{K}$ & $\mathrm{P}$ & $\mathrm{K}$ & $\mathrm{P}$ \\
\hline 18:00-18:30 & 21 & 1815 & 17 & 1260 & 13 & 1876 \\
18:30-19:00 & 21 & 1606 & 21 & 1652 & 18 & 1703 \\
19:00-19:30 & 22 & 1756 & 24 & 1784 & 11 & 1608 \\
19:30-20:00 & 14 & 1718 & 15 & 1760 & 17 & 1743 \\
20:00-20:30 & 15 & 1861 & 16 & 1781 & 24 & 1870 \\
20:00-21:00 & 14 & 1627 & 16 & 1652 & 23 & 696 \\
Jumlah & 107 & 10.383 & 109 & 9.889 & 106 & 9.496 \\
\hline
\end{tabular}

Tabel 1 menunjukan jumlah data kedatangan dan waktu pelayanan tiap pengunjung yang dilakukan selama 3 jam setiap hari Sabtu yaitu pada tanggal 09, 16, dan 23 Februari 2019. Pada hari Sabtu 09 Februari 2019 diperoleh 107 orang dan 10.383 menit selama 3 jam. Pada hari Sabtu 16 Februari 2019 diperoleh 109 orang dan 9.889 menit selama 3 jam. Pada hari Sabtu 23 Februari 2019 diperoleh 106 orang dan 9.496 menit selama 3 jam.

\section{Model Antrian}

Dari hasil analisis sistem nyata dan mekanisme pelayanan, diketahui sistem antrian yang digunakan pada bioskop termasuk dalam model single channel-singel phase. Dikatakan single channel karena hanya ada satu jalur untuk memasuki sistem pelayanan atau hanya ada satu fasilitas pelayanan dan singel phase karena hanya ada satu pelayanan atau sekumpulan tunggal operasi yang dilaksanakan. Setelah pelayanan, individu keluar dari sistem. Sehingga dapat

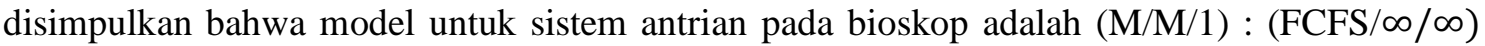
artinya jumlah kedatangan setiap satuan waktu mengikuti distribusi Poisson, waktu pelayanan berdistribusi eksponensial, banyaknya server sebanyak satu, disiplin antrian yang digunakan adalah First Come First Service (FCFS), sumber populasi tidak terbatas, dan panjang antrian tidak terbatas.

\section{Simulasi Model Antrian}

Tampilan awal pada program, terdapat kolom kedatangan dan pelayanan yang belum terisi masing-masing 6 kolom. Selanjutnya running program, yaitu menginput nilai kedatangan pada kolom pertama hingga kolom keenam begitupun dengan pelayanan, berdasarkan nilai yang telah diperoleh pada perhitungan sebelumnya. Hasil analisis akan muncul pada tampilan program setelah menekan dan memilih tombol "Proses Analisis". Jika ingin mengulang perhitungan atau nilai lambda lebih besar maka akan muncul perintah "Ulang". Kemudian tampilannya akan kembali ke tampilan awal yang telah siap untuk diinput kembali. Untuk mengakhiri analisis pada program, tekan tombol "Selesai" dan program akan ditutup. 


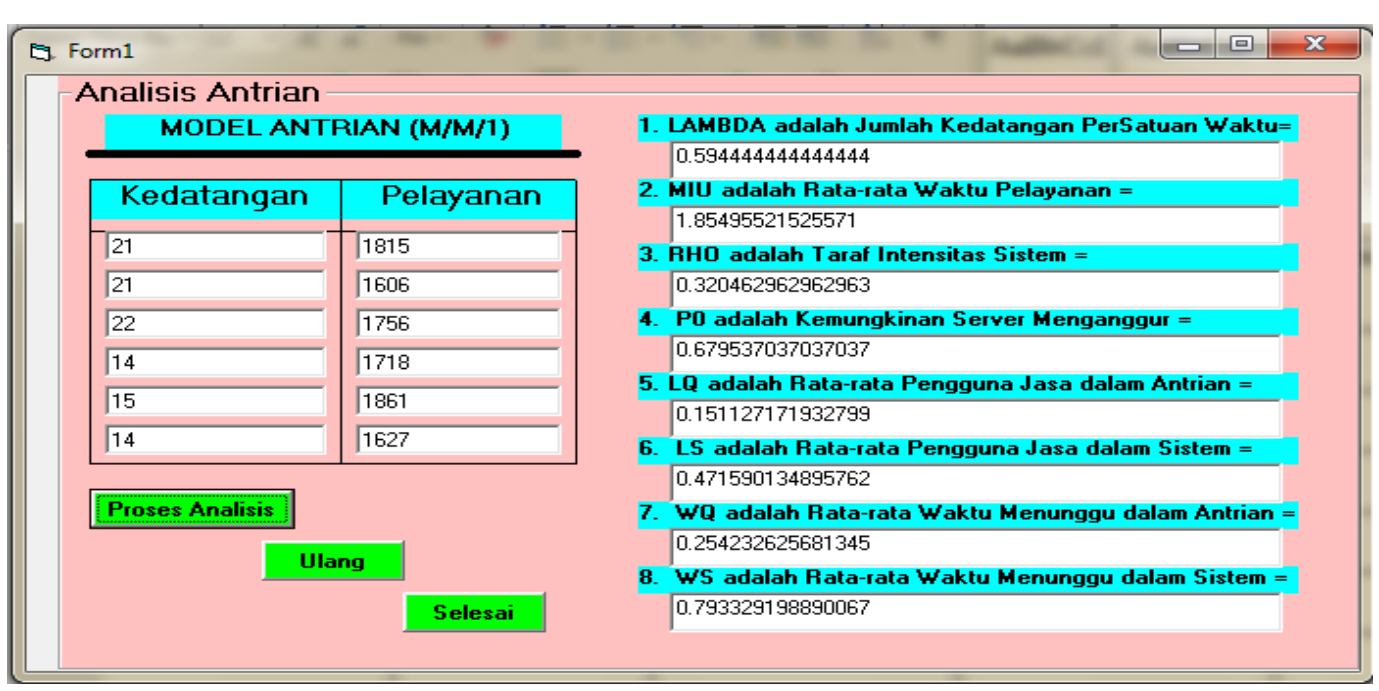

GAMBAR 1. Hasil Analisis Sistem Antrian pada Hari Sabtu, 09 Februari 2019 menggunakan Software Visual Basic.

Gambar 1 menunjukan bahwa banyaknya kedatangan pengunjung per satuan waktu, LAMBDA $(\lambda)$ adalah 0,59444. Hal ini menunjukan bahwa pengunjung yang datang sebanyak 0,59 pengunjung/menit. Selain itu, banyaknya pengunjung yang dilayani per satuan waktu, MIU $(\mu)$ adalah 1,85495. Ini mengisyaratkan bahwa lama pengunjung dilayani sebanyak 1,85 pengunjung/menit. Hasil taraf intensitas sistem, RHO $(\rho)$ adalah 0,32046. Artinya tingkat kesibukan server sebanyak $0,32 \%$. Adapun kemungkinan server menganggur $\left(P_{0}\right)$ adalah 0,69478. Hal ini berati bahwa peluang server mengganggur sebanyak 0,69\%. Banyaknya rata-rata pengguna jasa dalam antrian $(L q)$ adalah 0,15112 . Hal ini berarti bahwa jumlah ratarata menunggu dalam antrian sebanyak 0,15 pengunjung/menit. Selain itu, rata-rata pengguna jasa dalam system $(L s)$ adalah 0,47159 . Hal ini berarti bahwa rata-rata menunggu dalam sistem sebanyak 0,47 pengunjung/menit. Adapun rata-rata menunggu dalam antrian (Wq) adalah 0,25423 . Artinya waktu rata-rata menunggu dalam antrian sebanyak 0,25 menit. Banyaknya ratarata waktu menunggu dalam sistem (Ws) adalah 0,79332 . Hal ini menunjukan bahwa rata-rata waktu menunggu dalam sistem sebanyak 0,79 menit.

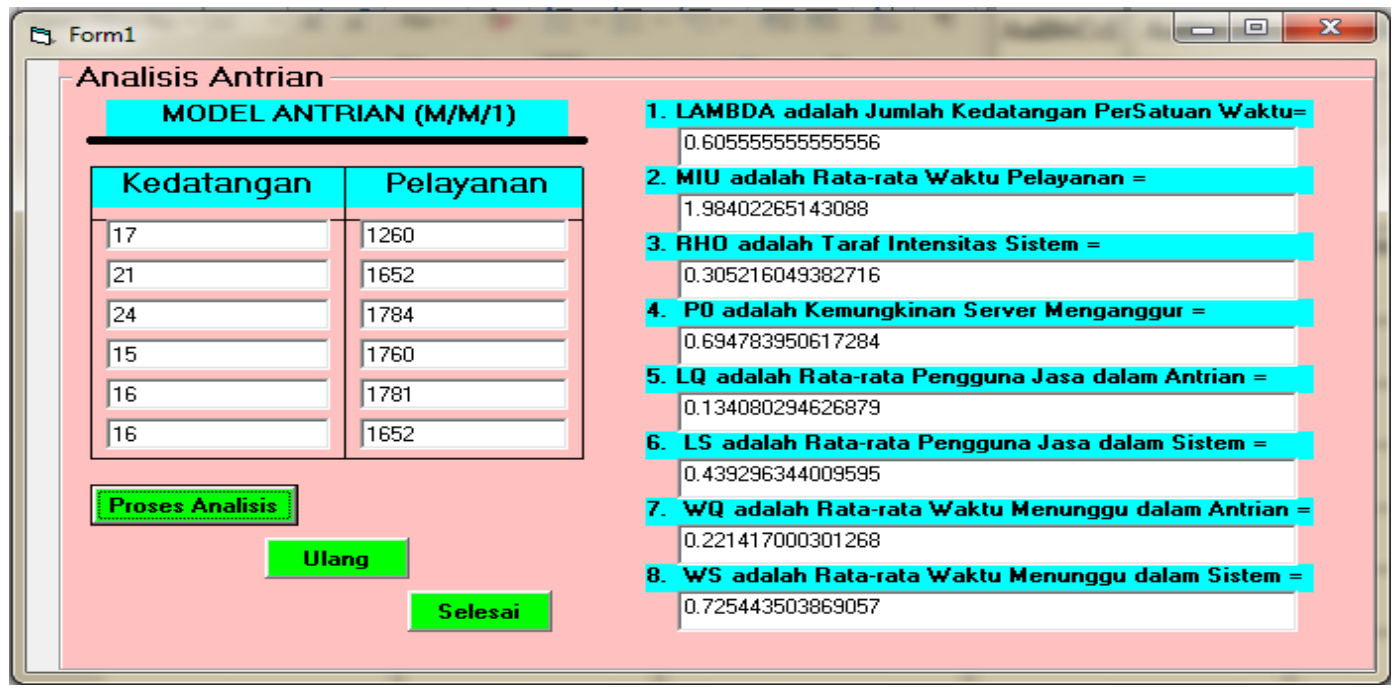

GAMBAR 2. Hasil Analisis Sistem Antrian pada Hari Sabtu, 16 Februari 2019 menggunakan Software Visual Basic. 
Gambar 2 menunjukan bahwa banyaknya kedatangan pengunjung per satuan waktu, LAMBDA $(\lambda)$ adalah 0,60555 . Hal ini menunjukan bahwa pengunjung yang datang sebanyak 0,60 pengunjung/menit. Selain itu, banyaknya pengunjung yang dilayani per satuan waktu, MIU $(\mu)$ adalah 1,98402. Hal ini mengisyaratkan bahwa lama pengunjung dilayani sebanyak 1,98 pengunjung/menit. Adapun taraf intensitas sistem, RHO $(\rho)$ adalah 0,30521. Artinya tingkat kesibukan server sebanyak $0,30 \%$. Banyaknya kemungkinan server menganggur $\left(P_{0}\right)$ adalah 0,69478. Hal ini berati bahwa peluang server mengganggur sebanyak 0,69\%. Adapun rata-rata pengguna jasa dalam antrian $(L q)$ adalah 0,13408 . Hal ini berarti bahwa jumlah ratarata menunggu dalam antrian sebanyak 0,13 pengunjung/menit. Selain itu, rata-rata pengguna jasa dalam sistem $(L s)$ adalah 0,43929. Artinya rata-rata menunggu dalam sistem sebanyak 0,43 pengunjung/menit. Banyaknya rata-rata menunggu dalam antrian (Wq) adalah 0,22141. Hal ini menunjukan bahwa waktu rata-rata menunggu dalam antrian sebanyak 0,22 menit. Adapun ratarata waktu menunggu dalam sistem (Ws) adalah 0,72544 . Artinya rata-rata waktu menunggu dalam sistem sebanyak 0,72 menit.

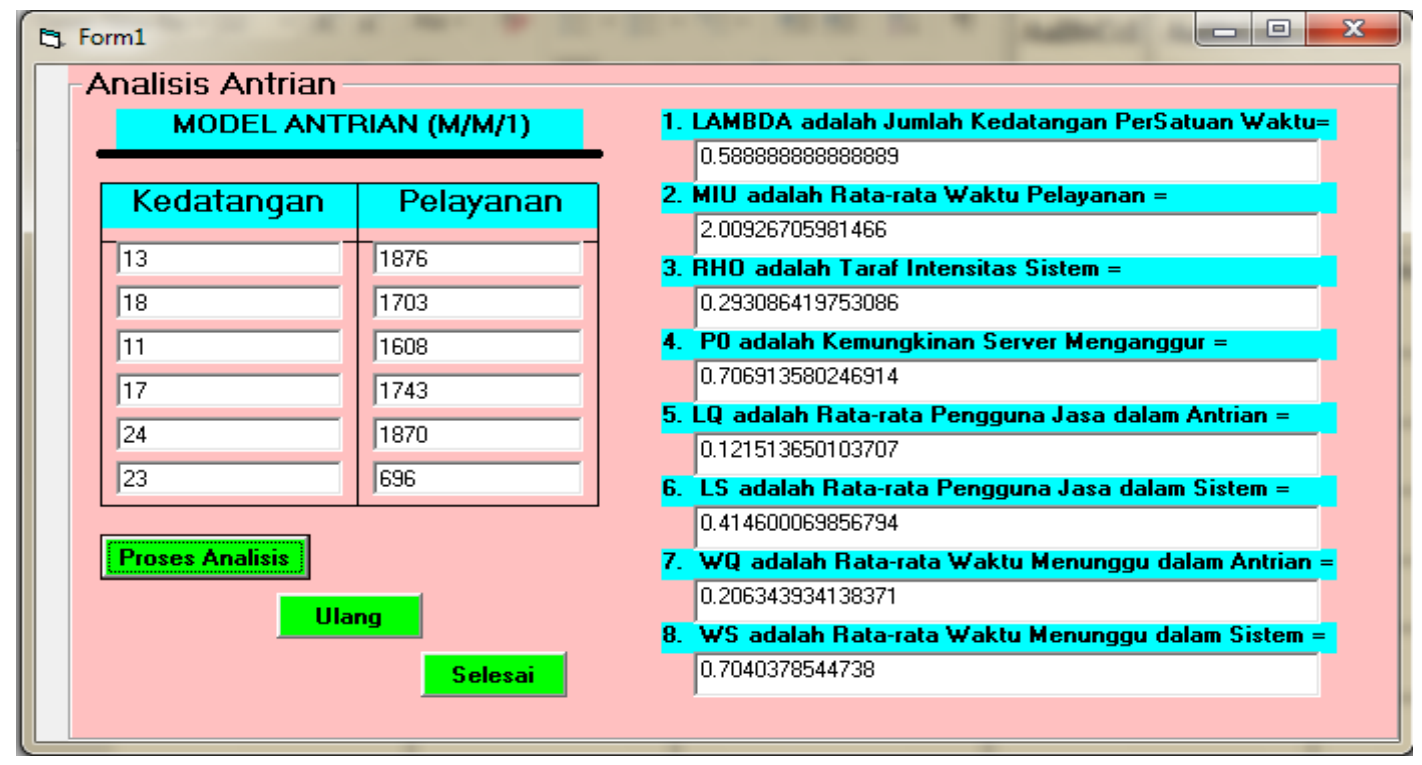

GAMBAR 3. Hasil Analisis Sistem Antrian pada Hari Sabtu, 23 Februari 2019 menggunakan Software Visual Basic.

Gambar 3 menunjukan bahwa banyaknya kedatangan pengunjung per satuan waktu, LAMBDA $(\lambda)$ adalah 0,58888 . Hal ini menunjukan bahwa pengunjung yang datang sebanyak 0,58 pengunjung/menit. Selain itu, banyaknya pengunjung yang dilayani per satuan waktu, MIU $(\mu)$ adalah 2,00926. Hal ini mengisyaratkan bahwa lama pengunjung dilayani sebanyak 2,00 pengunjung/menit. Adapun taraf intensitas sistem, RHO $(\rho)$ adalah 0,29308. Artinya bahwa tingkat kesibukan server sebanyak $0,29 \%$. Banyaknya kemungkinan server menganggur $\left(P_{0}\right)$ adalah 0,70691. Hal ini berarti bahwa peluang server mengganggur sebanyak $0,70 \%$. Selain itu, rata-rata pengguna jasa dalam antrian $(L q)$ adalah 0,12151 . Hal ini menunjukan bahwa jumlah rata-rata menunggu dalam antrian sebanyak 0,12 pengunjung/menit. Banyaknya rata-rata pengguna jasa dalam system ( $L s$ ) adalah 0,41460. Artinya rata-rata menunggu dalam sistem sebanyak 0,41 pengunjung/menit. Adapun rata-rata menunggu dalam antrian (Wq) adalah 0,20634 . Artinya waktu rata-rata menunggu dalam antrian sebanyak 0,20 menit. Selain itu ratarata waktu menunggu dalam sistem (Ws) adalah 0,70403. Hal ini menunjukan bahwa rata-rata waktu menunggu dalam sistem sebanyak 0,70 menit. 


\section{Evaluasi Sistem Antrian pada Bioskop 21 Mall Panakkukkang}

Berdasarkan hasil perhitungan manual dan perhitungan dengan menggunakan Software Visual Basic, dapat diperoleh hasil evaluasi sistem antrian:

1. Jumlah kedatangan per satuan waktu $(\lambda)$

$$
\lambda_{\text {rata-rata }}=\frac{\lambda_{1}+\lambda_{2}+\lambda_{3}}{3}=\frac{0,59+0,60+0,58}{3}=0,59 \text { pengunjung } / \text { menit. }
$$

2. Rata-rata waktu pelayanan $(\mu)$

$$
\mu_{\text {rata-rata }}=\frac{\mu_{1}+\mu_{2}+\mu_{3}}{3}=\frac{1,85+1,98+2,00}{3}=1,94 \text { pengunjung/menit. }
$$

3. Taraf intensitas sistem $(\rho)$

$$
\rho_{\text {rata-rata }}=\frac{\rho_{1}+\rho_{2}+\rho_{3}}{3}=\frac{0,32+0,30+0,29}{3}=0,30 \% .
$$

4. Kemungkinan server dalam keadaan menganggur $\left(P_{0}\right)$

$$
\rho_{\text {0rata-rata }}=\frac{\rho_{01}+\rho_{02}+\rho_{03}}{3}=\frac{0,67+0,69+0,70}{3}=0,69 \% \text {. }
$$

5. Rata-rata pengguna jasa dalam antrian $\left(\mathrm{L}_{\mathrm{q}}\right)$

$$
\mathrm{Lq}_{\text {rata-rata }}=\frac{\mathrm{Lq}_{1}+\mathrm{Lq}_{2}+\mathrm{Lq}_{3}}{3}=\frac{0,15+0,13+0,12}{3}=0,13 \text { pengunjung/menit. }
$$

6. Rata-rata pengguna jasa dalam sistem $\left(\mathrm{L}_{\mathrm{s}}\right)$

$$
\mathrm{Ls}_{\text {Rata-rata }}=\frac{\mathrm{Ls}_{1}+\mathrm{Ls}_{2}+\mathrm{Ls}_{3}}{3}=\frac{0,47+0,43+0,41}{3}=0,44 \text { pengunjung } / \text { menit. }
$$

7. Rata-rata waktu menunggu dalam antrian $\left(\mathrm{W}_{\mathrm{q}}\right)$

$$
\mathrm{Wq}_{\text {rata-rata }}=\frac{\mathrm{Wq}_{1}+\mathrm{Wq}_{2}+\mathrm{Wq}_{3}}{3}=\frac{0,25+0,22+0,20}{3}=0,22 \text { menit. }
$$

8. Rata-rata waktu menunggu dalam sistem $\left(\mathrm{W}_{\mathrm{s}}\right)$

$$
\mathrm{Ws}_{\text {rata-rata }}=\frac{\mathrm{Ws}_{1}+\mathrm{Ws}_{2}+\mathrm{Ws}_{3}}{3}=\frac{0,79+0,72+0,70}{3}=0,74 \text { menit. }
$$

Analisis sistem antrian mendekati sama maka akan dijelaskan pada Tabel 2.

TABEL 2. Data hasil perhitungan manual dan menggunakan software analisis Sistem antrian

\begin{tabular}{ccccccccc}
\hline Hari/tanggal & $\boldsymbol{\lambda}$ & $\boldsymbol{\mu}$ & $\boldsymbol{\rho}$ & $\mathbf{P 0}$ & Lq & Ls & Wq & Ws \\
\hline $\begin{array}{c}\text { Sabtu/09 } \\
\text { Februari 2019 }\end{array}$ & 0,59 & 1,85 & 0,32 & 0,68 & 0,15 & 0,47 & 0,25 & 0,79 \\
$\quad$ Sabtu/16 & 0,60 & 1,98 & 0,31 & 0,69 & 0,13 & 0,43 & 0,22 & 0,72 \\
$\begin{array}{c}\text { Februari 2019 } \\
\quad \text { Sabtu/23 }\end{array}$ & 0,58 & 2,00 & 0,29 & 0,71 & 0,12 & 0,41 & 0,20 & 0,70 \\
Februari 2019 & & & & & & & & \\
\hline
\end{tabular}

Tabel 2 menunjukan bahwa jumlah kedatangan per satuan waktu $(\lambda)$ sebesar 0,59 pengunjung/menit, rata-rata waktu pelayanan $(\mu)$ sebesar 1,94 pengunjung/menit, taraf intensitas sistem $(\rho)$ sebesar 0,31\%, kemungkinan server dalam keadaan menganggur $\left(P_{0}\right)$ sebesar $0,69 \%$, rata-rata pengguna jasa dalam antrian $\left(\mathrm{L}_{\mathrm{q}}\right)$ sebesar 0,13 pengunjung/menit, rata-rata pengguna jasa dalam sistem $\left(\mathrm{L}_{\mathrm{s}}\right)$ sebesar 0,44 pengunjung/menit, rata-rata waktu menunggu dalam antrian $\left(\mathrm{W}_{\mathrm{q}}\right)$ sebesar 0,22 menit, dan rata-rata waktu menunggu dalam sistem $\left(\mathrm{W}_{\mathrm{s}}\right)$ sebesar0,74 menit. 


\section{KESIMPULAN}

Antrian pada penelitian ini dikatakan sudah optimal dikarenakan lama pelayanan setiap pengunjung pembelian tiket Bioskop telah memenuhi standar pelayanan. Sedangkan untuk antrian pengunjung yang akan mendapatkan pelayanan telah optimal. Hal ini dikarenakan lama waktu menunggu dan lama waktu pelayanan pada loket terbilang singkat. Sehingga tidak perlu dilakukan penambahan ataupun pengurangan jumlah server pelayanan yang disediakan.

Penelitian lain yang dapat dilakukan yaitu dengan menggunakan model yang berbeda dengan memperoleh data yang lebih tinggi dalam menyelesaikan analisis system antrian. Dalam menganalisis model antrian, peneliti lainnya dapat menggunakan model yang lain seperti model single channel-multi phase, multi channel-singel phase dan multi channel-multi phase bahkan peneliti dapat membandingkan ketiga model.

\section{DAFTAR PUSTAKA}

Andika., Pardede, A.M.H., \& Novryanti. (2018). Simulasi Antrian Pelayanan Bank menggunakan Metode Eksponensial. Jurnal Sistem Informasi Kaputama, 2(1). 9-19.

Arwindy, F., Bu'ulolo, F., \& Rosmaini, E. (2014). Analisis dan Simulasi Sistem Antrian pada Bank ABC. Jurnal Saintia Matematika, 2(2). 147-162.

Heizer, J., \& Render, B. (2005). Operations Management. Jakarta: Salemba Empat.

Jatmika, S., \& Prasetyo, B.P.T. (2017). Analisis Antrian Model Multi Channel-Singel Phase dan Optimalisasi Layanan Akademik. Jurnal POSITIF, 3(1). 41-46.

Kakiay, T.J. (2004). Dasar Teori Antrian untuk Kehidupan Nyata. Yogyakarta: Andi.

Ratnasari, S., Rahadian, N., \& Liquidan, E. (2018). Pemodelan dan Simulasi Sistem Antrian Pelayanan Konsumen Gerai MCD Solo Grand Mall dengan Arena. Seminar dan Konferensi Nasional IDEC (7-8). Surakarta, Indonesia: USM.

Retnaningsih, S.M \& Irhamah. (2011). Riset Operasi. Surabaya: ITSPRESS.

Serlina, L. (2018). Analisis Sistem Antrian Pelanggang Rakyat Indonesia (BRI) Cabang Bandar Lampung (Skripsi). Universitas Islam Negeri Raden Intan Lampung, Lampung.

Setyawan, A.S. (2013). Analisis Sistem Antrian Layanan Teller pada Bank BRI KCP Jakenan Pati (Skripsi). Universitas Diponegoro, Semarang.

Silaban, D.C., \& Sulvin, M. (2015). Analisis Kinerja Sistem Antrian M/M/C. JURNAL SINGUDA ENSIKOM, 7(3). 165-170.

Sinalungga, S. (2008). Pengantar Teknik Industri. Yogyakarta: Graha Ilmu.

Suhartini, E.S. (2017). Model Antrian untuk Kapasitas Bandara Internasional Sultan Hasanuddin Makassar (Skripsi). Universitas Islam Negeri Makassar, Makassar. 